WOODHEAD PUBLISHING SERIES IN CIVIL AND STRUCTURAL ENGINEERING

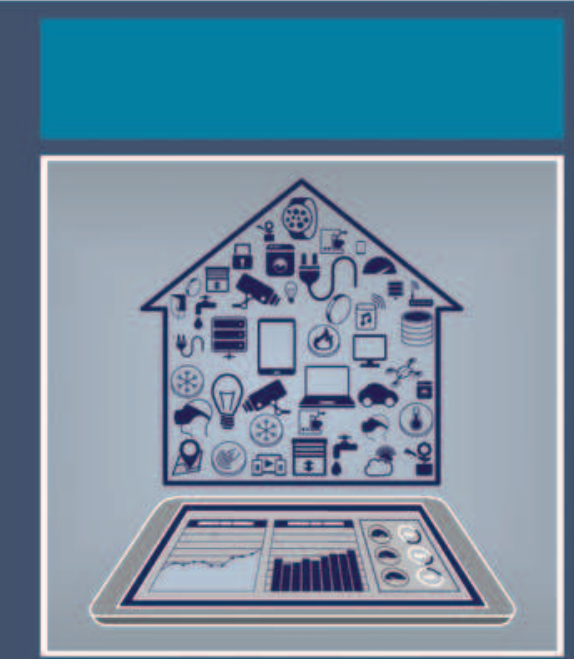

Start-Up Creation

The Smart Eco-Efficient

Built Environment

Edited by Fernando Pacheco-Torgal, Erik Rasmussen, Claes-Göran Granqvist, Volodymyr Ivanov, Arturas Kaklauskas and Stephen Makonin 
Start-Up Creation 


\section{Related titles}

Nonconventional and Vernacular Construction Materials: Characterisation, Properties and Applications

(ISBN 978-0-08-100871-3)

Biopolymers and Biotech Admixtures for Eco-Efficient Construction Materials (ISBN 978-0-08-100214-8)

Acoustic Emission and Related Non-destructive Evaluation Techniques in the Fracture Mechanics of Concrete: Fundamentals and Applications

(ISBN 978-1-78242-327-0) 
Woodhead Publishing Series in Civil and Structural Engineering: Number 66

\section{Start-Up Creation}

The Smart Eco-Efficient Built Environment

Edited by

Fernando Pacheco-Torgal, Erik Rasmussen, Claes-Göran Granqvist, Volodymyr Ivanov, Arturas Kaklauskas and Stephen Makonin

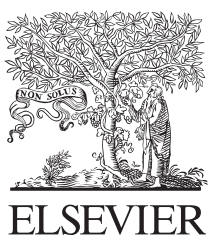


Woodhead Publishing is an imprint of Elsevier

The Officers' Mess Business Centre, Royston Road, Duxford, CB22 4QH, UK

50 Hampshire Street, 5th Floor, Cambridge, MA 02139, USA

The Boulevard, Langford Lane, Kidlington, OX5 1GB, UK

Copyright () 2016 Elsevier Ltd. All rights reserved.

No part of this publication may be reproduced or transmitted in any form or by any means, electronic or mechanical, including photocopying, recording, or any information storage and retrieval system, without permission in writing from the publisher. Details on how to seek permission, further information about the Publisher's permissions policies and our arrangements with organizations such as the Copyright Clearance Center and the Copyright Licensing Agency, can be found at our website: www.elsevier.com/permissions.

This book and the individual contributions contained in it are protected under copyright by the Publisher (other than as may be noted herein).

\section{Notices}

Knowledge and best practice in this field are constantly changing. As new research and experience broaden our understanding, changes in research methods, professional practices, or medical treatment may become necessary.

Practitioners and researchers must always rely on their own experience and knowledge in evaluating and using any information, methods, compounds, or experiments described herein. In using such information or methods they should be mindful of their own safety and the safety of others, including parties for whom they have a professional responsibility.

To the fullest extent of the law, neither the Publisher nor the authors, contributors, or editors, assume any liability for any injury and/or damage to persons or property as a matter of products liability, negligence or otherwise, or from any use or operation of any methods, products, instructions, or ideas contained in the material herein.

British Library Cataloguing-in-Publication Data

A catalogue record for this book is available from the British Library

Library of Congress Cataloging-in-Publication Data

A catalog record for this book is available from the Library of Congress

ISBN: 978-0-08-100546-0 (print)

ISBN: 978-0-08-100549-1 (online)

For information on all Woodhead Publishing publications visit our website at https://www.elsevier.com/

\begin{tabular}{|c|c|c|}
\hline 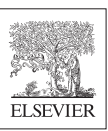 & Book Aid & $\begin{array}{l}\text { Working together } \\
\text { to grow libraries in } \\
\text { developing countries }\end{array}$ \\
\hline
\end{tabular}

Publisher: Matthew Deans

Acquisition Editor: Gwen Jones

Editorial Project Manager: Charlotte Cockle

Production Project Manager: Debasish Ghosh

Designer: Greg Harris

Typeset by TNQ Books and Journals 


\section{Contents}

List of contributors $\quad$ xi

Woodhead Publishing Series in Civil and Structural Engineering xiii

Foreword

xvii

1 Introduction to start-up creation for the smart eco-efficient built environment

F. Pacheco-Torgal

1.1 A brief introduction to entrepreneurship and start-up creation

1.2 Smart eco-efficient built environment: an untouched start-up pond? $\quad \mathbf{4}$

1.3 Outline of the book 9

References $\quad 11$

Part One Business plans, start-up financing, marketing, creativity and intellectual property marketing

2 Business plan basics for engineers $\quad 21$

S. Tanev, E.S. Rasmussen, K.R. Hansen
$2.1 \quad$ Introduction

2.2 How to approach business planning for engineers $\mathbf{2 6}$

2.3 Developing and articulating the business model: the lean
canvas approach

2.4 Scaling up the business $\quad 30$

2.5 A business plan template $\quad 33$

2.6 Conclusion $\quad \mathbf{3 5}$

References $\quad 36$

$3 \quad$ Lean start-up: making the start-up more successful 39

E.S. Rasmussen, S. Tanev

3.1 Introduction $\quad 39$

3.2 The main elements of lean start-ups $\quad \mathbf{4 3}$

3.3 The key concepts of lean start-ups $\quad \mathbf{4 5}$

3.4 Some examples of lean processes $\quad \mathbf{5 4}$

3.5 Conclusion and future trends $\quad \mathbf{5 4}$

Web resources $\quad \mathbf{5 5}$

References $\quad \mathbf{5 5}$ 
4 Start-up financing

S.C. Oranburg

4.1 Introduction

4.2 Debt financing

4.3 Equity financing

4.4 Convertible debt financing

4.5 Crowdfunding

4.6 Conclusions and future trends

References

5 Marketing for start-ups

T. Shih

5.1 Introduction

5.2 Conceptual framework

5.3 Case studies

5.4 Concluding discussion

References

6 A minimalist model for measuring entrepreneurial creativity in eco-systems

E. Carayannis, P. Harvard

6.1 A savvy Scotsman

6.2 An impossible Irishman

6.3 An eccentric Englishman

6.4 Conclusion

References

7 Intellectual property

A. Caplanova

7.1 Introduction

7.2 Forms of intellectual property rights

7.3 Historical development of the intellectual property protection

7.4 Regulatory aspects of intellectual property protection

7.5 Some considerations of the intellectual property protection for start-up businesses

7.6 Conclusions

\section{Part Two Nano and biotechnologies for eco-efficient buildings}

8 Nano-based thermal insulation for energy-efficient buildings 
8.3 Traditional thermal building insulation $\mathbf{1 3 1}$

8.4 State-of-the-art thermal building insulation $\mathbf{1 3 3}$

8.5 Nanotechnology applied on thermal insulation $\mathbf{1 3 8}$

8.6 Concepts for future thermal building insulation $\mathbf{1 3 9}$

8.7 A comparison of weaknesses and strengths $\quad \mathbf{1 4 7}$

8.8 Experimental pathways $\quad \mathbf{1 6 0}$

8.9 Experimental synthesis of hollow silica nanospheres $\mathbf{1 6 3}$

8.10 Start-up creation of nano-based thermal insulation $\quad \mathbf{1 6 6}$

$\begin{array}{lll}8.11 & \text { Future perspectives for the research paths ahead } & \mathbf{1 6 7}\end{array}$

$\begin{array}{ll}8.12 \text { Conclusions } & 169\end{array}$

Acknowledgments $\quad 170$

References $\quad 170$

9 Nano-based phase change materials for building energy efficiency 183

Dr. K. Biswas

$\begin{array}{lll}9.1 & \text { Introduction } & \mathbf{1 8 3}\end{array}$

$\begin{array}{ll}\text { 9.2 Classification of phase change materials } & \mathbf{1 8 4}\end{array}$

9.3 Synthesis of nano phase change materials $\quad \mathbf{1 8 6}$

$\begin{array}{ll}9.4 & \mathbf{1 9} \\ \mathbf{1 9 2}\end{array}$

$\begin{array}{lll}9.5 & \text { Building applications } & 197\end{array}$

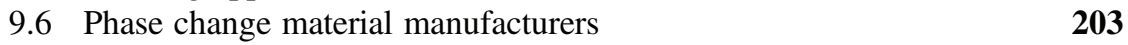

$\begin{array}{lll}9.7 & \text { Summary and conclusions } & \mathbf{2 0 5}\end{array}$

$\begin{array}{lll}9.8 & \text { Future research } & \mathbf{2 0 5}\end{array}$

Nomenclature $\quad 206$

Acknowledgments $\quad 207$

$\begin{array}{ll}\text { References } & \mathbf{2 0 7}\end{array}$

10 Nano-based chromogenic technologies for building energy efficiency 213

L. Long, H. Ye

$\begin{array}{lll}10.1 & \text { Introduction } & \mathbf{2 1 3}\end{array}$

$\begin{array}{lll}10.2 & \text { Chromogenic technologies } & \mathbf{2 1 4}\end{array}$

10.3 Performance demonstrations $\quad \mathbf{2 1 6}$

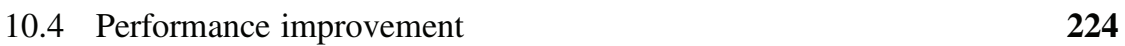

10.5 Conclusions and future trends $\quad 232$

References $\quad 233$

11 Façade integrated photobioreactors for building energy efficiency $\quad 237$

S.Ş. Öncel, A. Köse, D.Ş. Öncel

$\begin{array}{lll}11.1 & \text { Introduction } & \mathbf{2 3 7}\end{array}$

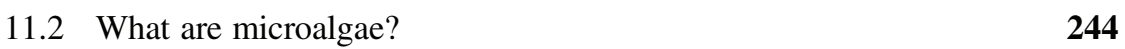

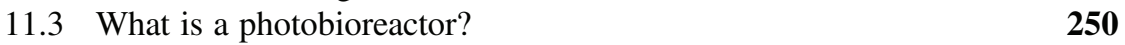

11.4 Potential role of photobioreactor systems in building $\mathbf{2 6 5}$ 
11.5 The realization of a façade photobioreactor-integrated building for the future

11.6 Microalgae, a green volunteer for a better building: looking from an objective perspective for a start-up

11.7 Conclusion

Acknowledgments

References

12 Biotechnologies for improving indoor air quality

G. Soreanu

12.1 Introduction

12.2 Issues of air pollution in indoor environments

12.3 Biotechnologies for air treatment: a brief theoretical background

12.4 Application of biotechnologies for improving air quality in indoors

12.5 Conclusions

13 Bio-based plastics for building facades

C. Köhler-Hammer, J. Knippers, M.R. Hammer

13.1 Introduction

13.2 Feedstock

13.3 Ecological advantages and resource efficiency

13.4 Recycling and disposal

13.5 Technical and design aspects

331

13.6 Requirements

332

13.7 Possible thermoplastic bio-based plastics and material selection

13.8 Fire tests

13.9 Heat resistance and possibilities

13.10 Resistance to weather $\quad 337$

13.11 Further opportunities to improve properties 339

$\begin{array}{ll}13.12 \text { Biopolymers: scope for design } & 339\end{array}$

13.13 Facade mock-up $\quad \mathbf{3 4 2}$

$\begin{array}{ll}13.14 \text { Conclusion } & 344\end{array}$

References $\quad 344$

\section{Part Three Algorithms, big data and Iot for eco-efficient and smart buildings}

14 Development of algorithms for building retrofit

F. Cappelletti, P. Penna, A. Prada, A. Gasparella

14.1 Introduction

14.2 Methods for the choice of energy-efficiency measures for building retrofit

14.3 Algorithms for the implementation of multiobjective optimization 
14.4 Application example: optimization of energy retrofit measures applied on residential buildings

14.5 Conclusion

References

15 The use of algorithms for light control

C. Cristalli, L. Standardi, D. Kolokotsa, S. Papantoniou

$\begin{array}{ll}\text { 15.1 Introduction } & \mathbf{3 7 5}\end{array}$

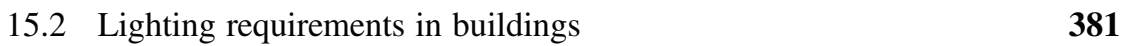

15.3 Development of light-control algorithms 382

15.4 Integration and implementation of the control algorithms in pilot buildings

15.5 Conclusion

Acknowledgments

References

16 Big data analytics and cloud computing for sustainable building energy efficiency

J.-S. Chou, N.-T. Ngo, W.K. Chong, G.E. Gibson Jr.

16.1 Introduction

16.2 Literature review of building energy management systems

16.3 Overview of big data and cloud computing technologies

16.4 Framework design of the proposed smart decision support system for building energy efficiency

16.5 Conclusions

References

17 Intelligent decision-support systems and the Internet of Things for the smart built environment

A. Kaklauskas, R. Gudauskas

17.1 Introduction

17.2 Domain-specific examples and applications

17.3 Machine-to-machine

17.4 Intelligent decision-support systems for Internet of Things

17.5 The trends and future of the Internet of Things

17.6 Internet of Things start-ups

Acknowledgments

References

18 App programming and its use in smart buildings

18.2 Types of apps 
18.3 Methodologies for creating apps $\quad 457$

18.4 Conclusions $\quad \mathbf{4 6 2}$

References $\quad 462$

19 Apps for smart buildings: a case study on building security 465

I. Chatzigiannakis

19.1 Introduction $\quad \mathbf{4 6 5}$

19.2 Networking technologies for smart homes $\mathbf{4 6 6}$

19.3 The vulnerability of wireless networks: a case of cyber-security threat

19.4 Reinforcing the security of wireless communications: the case of smart locks

19.5 The need for secure data exchange and storage

19.6 The need for innovative approaches to handle data generated: the case of smart cameras

19.7 Smart home products: a fragmented landscape $\mathbf{4 7 5}$

$\begin{array}{ll}19.8 \text { Conclusions and future trends } & \mathbf{4 7 7}\end{array}$ References $\quad \mathbf{4 7 8}$

Index 


\section{List of contributors}

Dr. K. Biswas Oak Ridge National Laboratory, Oak Ridge, TN, United States

A. Caplanova University of Economics in Bratislava, Bratislava, Slovakia

F. Cappelletti University Iuav of Venice, Venice, Italy

E. Carayannis Professor George Washington University

I. Chatzigiannakis Sapienza University of Rome, Rome, Italy

W.K. Chong Arizona State University, Tempe, AZ, United States

J.-S. Chou National Taiwan University of Science and Technology, Taipei, Taiwan; Arizona State University, Tempe, AZ, United States

C. Cristalli Loccioni Group, Angeli di Rosora, (An), Italy

A. Gasparella Free University of Bozen-Bolzano, Bolzano, Italy

G.E. Gibson Jr. Arizona State University, Tempe, AZ, United States

R. Gudauskas Vilnius Gediminas Technical University, Vilnius, Lithuania

M.R. Hammer University of Stuttgart, Stuttgart, Germany

K.R. Hansen University of Southern Denmark, Odense, Denmark

P. Harvard Professor EIGSI Engineering School France

Bjørn Petter Jelle Norwegian University of Science and Technology (NTNU), Trondheim, Norway; SINTEF Building and Infrastructure, Trondheim, Norway

A. Kaklauskas Vilnius Gediminas Technical University, Vilnius, Lithuania

J. Knippers University of Stuttgart, Stuttgart, Germany

C. Köhler-Hammer University of Stuttgart, Stuttgart, Germany

D. Kolokotsa Technical University of Crete, Chania, Greece

A. Köse Ege University, Izmir, Türkiye

L. Long University of Science and Technology of China, Hefei, PR China

S. Makonin Simon Fraser University, Burnaby, BC, Canada 
N.-T. Ngo National Taiwan University of Science and Technology, Taipei, Taiwan S.Ş. Öncel Ege University, Izmir, Türkiye

D.Ş. Öncel Dokuz Eylul University, Izmir, Türkiye

S.C. Oranburg Chicago-Kent College of Law, Chicago, IL, United States

F. Pacheco-Torgal University of Minho, Guimarães, Portugal

S. Papantoniou Technical University of Crete, Chania, Greece

P. Penna Free University of Bozen-Bolzano, Bolzano, Italy

A. Prada Free University of Bozen-Bolzano, Bolzano, Italy

E.S. Rasmussen University of Southern Denmark, Odense, Denmark

T. Shih Lund University, Lund, Sweden

G. Soreanu Technical University "Gheorghe Asachi” of Iasi, Faculty of Chemical Engineering and Environmental Protection, Department of Environmental Engineering and Management, Iasi, Romania

L. Standardi Loccioni Group, Angeli di Rosora, (An), Italy

S. Tanev University of Southern Denmark, Odense, Denmark

H. Ye University of Science and Technology of China, Hefei, PR China 


\section{Woodhead Publishing Series in Civil and Structural Engineering}

1 Finite element techniques in structural mechanics

C. T. F. Ross

2 Finite element programs in structural engineering and continuum mechanics C. T. F. Ross

3 Macro-engineering F. P. Davidson, E. G. Frankl and C. L. Meador

4 Macro-engineering and the earth U. W. Kitzinger and E. G. Frankel

5 Strengthening of reinforced concrete structures Edited by L. C. Hollaway and M. Leeming

6 Analysis of engineering structures B. Bedenik and C. B. Besant

7 Mechanics of solids C. T. F. Ross

$8 \quad$ Plasticity for engineers C. R. Calladine

9 Elastic beams and frames J. D. Renton

10 Introduction to structures $W$. R. Spillers

11 Applied elasticity J. D. Renton

12 Durability of engineering structures J. Bijen

13 Advanced polymer composites for structural applications in construction Edited by L. C. Hollaway

14 Corrosion in reinforced concrete structures Edited by H. Böhni

15 The deformation and processing of structural materials Edited by Z. X. Guo

16 Inspection and monitoring techniques for bridges and civil structures Edited by $G$. Fu

17 Advanced civil infrastructure materials Edited by $\mathrm{H}$. Wu

18 Analysis and design of plated structures Volume 1: Stability Edited by E. Shanmugam and C. M. Wang 
19 Analysis and design of plated structures Volume 2: Dynamics Edited by E. Shanmugam and C. M. Wang

20 Multiscale materials modelling Edited by Z. X. Guo

21 Durability of concrete and cement composites Edited by C. L. Page and M. M. Page

22 Durability of composites for civil structural applications Edited by V. M. Karbhari

23 Design and optimization of metal structures J. Farkas and K. Jarmai

24 Developments in the formulation and reinforcement of concrete Edited by $S$. Mindess

25 Strengthening and rehabilitation of civil infrastructures using fibre-reinforced polymer (FRP) composites

Edited by L. C. Hollaway and J. C. Teng

26 Condition assessment of aged structures Edited by J. K. Paik and R. M. Melchers

27 Sustainability of construction materials J. Khatib

28 Structural dynamics of earthquake engineering S. Rajasekaran

29 Geopolymers: Structures, processing, properties and industrial applications Edited by J. L. Provis and J. S. J. van Deventer

30 Structural health monitoring of civil infrastructure systems Edited by V. M. Karbhari and F. Ansari

31 Architectural glass to resist seismic and extreme climatic events Edited by R. A. Behr

32 Failure, distress and repair of concrete structures Edited by N. Delatte

33 Blast protection of civil infrastructures and vehicles using composites Edited by N. Uddin

34 Non-destructive evaluation of reinforced concrete structures Volume 1: Deterioration processes

Edited by C. Maierhofer, H.-W. Reinhardt and G. Dobmann

35 Non-destructive evaluation of reinforced concrete structures Volume 2: Non-destructive testing methods Edited by C. Maierhofer, H.-W. Reinhardt and G. Dobmann

36 Service life estimation and extension of civil engineering structures Edited by V. M. Karbhari and L. S. Lee

37 Building decorative materials Edited by Y. Li and S. Ren

38 Building materials in civil engineering Edited by $H$. Zhang

39 Polymer modified bitumen Edited by T. McNally

40 Understanding the rheology of concrete Edited by N. Roussel

41 Toxicity of building materials Edited by F. Pacheco-Torgal, S. Jalali and A. Fucic 
42 Eco-efficient concrete

Edited by F. Pacheco-Torgal, S. Jalali, J. Labrincha and V. M. John

43 Nanotechnology in eco-efficient construction

Edited by F. Pacheco-Torgal, M. V. Diamanti, A. Nazari and C. Goran-Granqvist

44 Handbook of seismic risk analysis and management of civil infrastructure systems Edited by F. Tesfamariam and K. Goda

45 Developments in fiber-reinforced polymer (FRP) composites for civil engineering Edited by N. Uddin

46 Advanced fibre-reinforced polymer (FRP) composites for structural applications Edited by J. Bai

47 Handbook of recycled concrete and demolition waste Edited by F. Pacheco-Torgal, V. W. Y. Tam, J. A. Labrincha, Y. Ding and J. de Brito

48 Understanding the tensile properties of concrete Edited by J. Weerheijm

49 Eco-efficient construction and building materials: Life cycle assessment (LCA), eco-labelling and case studies Edited by F. Pacheco-Torgal, L. F. Cabeza, J. Labrincha and A. de Magalhães

50 Advanced composites in bridge construction and repair Edited by Y. J. Kim

51 Rehabilitation of metallic civil infrastructure using fiber-reinforced polymer (FRP) composites Edited by V. Karbhari

52 Rehabilitation of pipelines using fiber-reinforced polymer (FRP) composites Edited by V. Karbhari

53 Transport properties of concrete: Measurement and applications P. A. Claisse

54 Handbook of alkali-activated cements, mortars and concretes F. Pacheco-Torgal, J. A. Labrincha, C. Leonelli, A. Palomo and P. Chindaprasirt

55 Eco-efficient masonry bricks and blocks: Design, properties and durability F. Pacheco-Torgal, P. B. Lourenço, J. A. Labrincha, S. Kumar and P. Chindaprasirt

56 Advances in asphalt materials: Road and pavement construction Edited by S.-C. Huang and H. Di Benedetto

57 Acoustic emission (AE) and related non-destructive evaluation (NDE) techniques in the fracture mechanics of concrete: Fundamentals and applications Edited by M. Ohtsu

58 Nonconventional and vernacular construction materials: Characterisation, properties and applications Edited by K. A. Harries and B. Sharma

59 Science and technology of concrete admixtures Edited by P.-C. Aitcin and R. J. Flatt

60 Textile fibre composites in civil engineering Edited by $T$. Triantafillou

61 Corrosion of steel in concrete structures Edited by A. Poursaee

62 Innovative developments of advanced multifunctional nanocomposites in civil and structural engineering Edited by K. J. Loh and S. Nagarajaiah

63 Biopolymers and biotech admixtures for eco-efficient construction materials Edited by F. Pacheco-Torgal, V. Ivanov, N. Karak and H. Jonkers 
64 Marine concrete structures: Design, durability and performance Edited by M. Alexander

65 Recent trends in cold-formed steel construction Edited by $C . Y u$

66 Start-up creation: The smart eco-efficient built environment Edited by F. Pacheco-Torgal, E. Rasmussen, C.-G. Granqvist, V. Ivanov, A. Kaklauskas and S. Makonin

67 Characteristics and uses of steel slag in building construction I. Barisic, I. Netinger, A. Fučić and S. Bansode 


\section{Foreword}

Start-up companies are just one, but a valuable way towards progressing innovation so that people in the built environment may have a healthier place to live and work. The barriers to the pathway of innovation are many. For success, there needs to be a fruitful collaboration between academia and industry, but often this also depends on Government policies which can encourage cooperative ventures. Academics need to have entrepreneurship as part of their portfolio, but this needs time and perseverance besides communication skills and some either do not or can see this as time they need to concentrate on the research. Industry and commercial outlooks towards innovation vary a lot. Some industries are very conservative and tend to think more short term whereas other sectors take the long-term view. In 19 chapters, this book covers all the range of possibilities that need consideration when contemplating a start-up company besides describing some of the latest innovations which offer new opportunities for achieving energy-efficient buildings. The best ideas are those that start with a defined focus such as energy efficiency but then bring added value by, for example, improving the human conditions. It is important that academics produce convincing business cases in their proposals for seeking any financial investment. Often industry tends to look at capital cost whereas the most innovative ones are more likely to look at the value so balancing the benefits and whole life costs of any proposal. There are lessons to be learnt from forward looking across sectors to the likes of information technology, aeronautics and pharmaceuticals, for example. Start-up companies need to be lean, adaptable and open with a wide range of technical and business skills. This book is welcome as it fills a gap in the market for eco-efficient scientists who want to understand how their work can make an impact on the industry.

Derek Clements-Croome

Professor Emeritus in Architectural Engineering

Reading University United Kingdom 
This page intentionally left blank 


\title{
Introduction to start-up creation for the smart eco-efficient built environment
}

\author{
F. Pacheco-Torgal \\ University of Minho, Guimarães, Portugal
}

\subsection{A brief introduction to entrepreneurship and start-up creation}

The paramount importance of entrepreneurs (and entrepreneurship) for economic development is mainly associated with the theoretical work of Joseph Schumpeter (1934). According to this economist entrepreneurs are key for the process of industrial mutation "that incessantly revolutionizes the economic structure from within, incessantly destroying the old one, incessantly creating a new one." For Schumpeter, innovations are disruptions that emanate from a pathological behavior, a social deviance from norms, from daring entrepreneurs (Louçã, 2014). However, and according to Leyden et al. (2014), the concept of the entrepreneur as an innovator precedes the work of Schumpeter (1934), dating back to the writings of Nicolas Baudeau in the 18th century (Baudeau, 1910) and the works of the economist Richard Cantillon as the first economist to recognize the importance of entrepreneurs to lead with uncertainty.

Kirchhoff (1989) emphasized the importance of entry and growth of new small firms as the sign of Schumpeter's "Creative Destruction" being the mark of the new entrepreneurial economy and the driving force underlying innovation and economic growth (Thurik et al., 2013). Start-up creation is especially important in the current knowledge-based economy in which knowledge production is shifting from universities to highly flexible multidisciplinary teams (Hsu et al., 2014). Despite that view, some still believe that in the next few years universities will continue to be the major sources of knowledge generation (Godin and Gingras, 2000). The truth is that its (indirect) role on the technology transfer process by providing highly qualified engineers to industry (as they did in the past) will no longer be considered enough. A European Union report (STAC, 2014) states that knowledge generation is no longer enough and emphasizes the need to translate knowledge into products and services. Universities will then have to face increased pressure to turn investigation budgets into profitable products and services (Kalar and Antoncic, 2015; Guerrero et al., 2015). According to Etzkowitz (2003) the universities' assumption of an entrepreneurial role constitutes the latest step in the evolution of a medieval institution from its original purpose of conservation of knowledge. This author points out that in

Start-Up Creation. http://dx.doi.org/10.1016/B978-0-08-100546-0.00001-7 Copyright $\odot 2016$ Elsevier Ltd. All rights reserved. 
US universities this evolution replaced the 19th century model of a single professor representing a discipline surrounded by a staff of assistants by a more democratic model in which, for instance, an assistant professor can set research directions if he or she can obtain outside research funding. This issue is especially important because around the world hundreds of universities still live by the outdated 19th century model. The interactions between universities, government, and industry (triple helix model) are and will be crucial for the development of the knowledge-based economy (Leydesdorff and Etzkowitz, 2001).

The germination of biomedical research in the 1970s, the passage of the Bayh-Dole act in 1980 (Mowery et al., 2001; Mowery and Ziedonis, 2002), and the increased financing of research by industry (Mowery et al., 2004) not only explain the increased rate in university spinoffs that occurred in the last decades but are the consequence of the triple helix model. However, only recently has the scientific community tried to explain why different universities show very different spinoff creation rates. In this respect Di Gregorio and Shane (2003) studied 101 US universities. Their hypothesis for the different spinoff generations encompassed intellectual eminence, the existence equity investment policies, and a low inventor's share of royalties. O'Shea et al. (2005) also studied US university-based spinoffs. For that they analyzed the spinoffs created in the top 20 US universities for the period 1980-2001 in which the Massachusetts Institute of Technology (MIT) had a lead position. These authors showed that spinoff creation is very dependent on university resource stock availability. These authors also confirmed the importance of intellectual eminence in faculty with critical expertise to create radical innovations that are essential for spinoff creation. Landry et al. (2006) analyzed a sample of 1554 Canadian researchers in natural sciences and engineering to understand the determinants of the creation of university spinoffs by Canadian researchers. They noticed that university laboratory assets are especially important for spinoff creation. They also noticed that the existence of experienced researchers and the degree of novelty of research knowledge have the largest marginal impact on the likelihood of university spinoff creation.

Krabel and Mueller (2009) state that scientists who hold a patent are four times more likely to be nascent entrepreneurs than those scientists without a patent. Astebro et al. (2012) reviewed three case studies known for their high percentage of student alumni that start new businesses. This included the case of MIT and two others from Swedish universities (Halmstad and Chalmers). These authors state that MIT is a unique case very hard to replicate because it combines an entrepreneurial culture with cutting edge research and a research budget that exceeds one billion dollars. The MIT exceptionality for spinoff creation was also highlighted by Roberts (2014). Astebro et al. (2012) pointed out the success of the Chalmers surrogate entrepreneur concept, where a student is chosen/hired specifically to develop the new venture. The reason for that has to do with the fact that the surrogate entrepreneur not only will add new entrepreneurial competence but also new network capability. This concept is based on a three-part division ownership rights. The university is entitled to one-third, the inventor to another third, and the remaining third to the surrogate entrepreneur. Lundqvist (2014) analyzed a total of 170 ventures; 35\% were surrogate-based. The results show that the surrogate ventures outperformed 
nonsurrogate ventures both in terms of growth and revenue. The surrogate entrepreneurship concept is therefore a virtuous one because surrogate entrepreneurs will contribute to a more balanced distribution of expertise among the start-up team members, which is known to be a start-up success factor (Maidique and Zirger, 1984; Roure and Keeley, 1990).

The lack of knowledge of the commercialization part of the entrepreneurial process is recognized as a gap in faculty (Siegel et al., 2007). And the work of Visintin and Pittino (2014) carried out on a sample of 103 Italian spinoffs confirms the importance of the surrogate entrepreneur concept and of the proper balance between scientific and commercial expertise of the team members. Those authors also mention that team members' high profile differentiation could constitute a pressure toward separation, requiring that team members must share some common characteristics to counterbalance that pressure. Other authors (de Lemos, 2014) also confirm that interpersonal relationship problems is the most critical factor that leads to the failure of technology start-ups. Using a sample of 2304 entrepreneurs who have started new businesses, Cassar (2014) investigated the role of experience on entrepreneurs' forecast performance regarding new business growth, and found that entrepreneurs with greater industry experience have more realistic expectations. Still this finding says very little about the start-up success by experienced entrepreneurs.

Ouimet and Zarutskie (2014) state that start-up creation is dependent on the availability of young workers. And Teixeira and Coimbra (2014) recently showed that younger start-up members reveal higher levels of entrepreneurial spirit and entrepreneurial capabilities, being in a better position to internationalize earlier than older members. It is worth mentioning that the average start-up member funded by the Silicon Valley Y Combinator (YC) is around 29 years old-a typical Y-generation (millennial), known for having a high entrepreneurial spirit (Winograd and Hais, 2014). Founded by Paul Graham in March of 2005, YC was the first start-up accelerator and so far has funded over 800 start-ups with a combined value over $\$ 30$ billion (YC, 2015).

Start-up accelerators are composed of four main features: a highly competitive application process (YC selects around 2\% of applicant start-up (Stagars, 2014)); provision of preseed investment in exchange for equity; focus on small teams instead of individual founders; time-limited support comprising programmed events and cohorts or classes of start-ups rather than individual companies (Miller and Bound, 2011). In the last decade this new incubating technology variant has grown very rapidly, exceeding thousands of new accelerators across the globe (Cohen and Hochberg, 2014).

Another important aspect that may help boost start-up creation concerns crowdfunding. This is an innovative funding method in which start-ups raise capital from small contributions of a very large number of individuals. Crowdfunding is especially important in a context in which banks are much less prone to lend money than before the 2008 financial crisis, and because start-ups do not have a financial history that would make it harder to get bank funding. Is not without irony that this alternative financing scenario that matches enterprises and investors could turn out to be a much better and sustainable solution for funding the economy (Macauley, 2015). 
Different crowdfunding business models are identified: donation, passive investment, and active investment (Schwienbacher and Larralde, 2012). So far crowdfunding has financed thousands of entrepreneurial ventures and the global crowdfunding market is expected to reach $\$ 93$ billion by 2025 (Swart, 2013). In the United States, the Jumpstart Our Business Start-ups (JOBS) Act signed into law on April 5, 2012, to legalize equity crowdfunding and enable entrepreneurs and small business owners to sell limited amounts of equity in their companies to a large number of investors via social networks and various Internet platforms (Stemler, 2013).

Kickstarter, the largest crowdfunding site, has already funded 48,526 US-based projects, amounting to $\$ 237$ million (Mollick, 2014). This helps to explain why the United States dominates global crowdfunding with $72 \%$ whereas the shares of Europe and the rest of the world were $26 \%$ and $2 \%$, respectively (Kshetri, 2015).

Distinguished Prof. Willian Baumol (2008) stated that promoting entrepreneurship and small firms would play a critical role for economic prosperity. Also in the current context of high graduate unemployment rates that will be more dramatic in the next decades (Biavaschi et al., 2015; Li et al., 2014; Roy, 2014; Schmid, 2015; Sadler, 2015; Min, 2015), a context in which tacit knowledge and formal education is recognized as not being enough (Lacy, 2011; Wagner, 2012; Agarwal and Shah, 2014; Thiel and Masters, 2014), start-up creation could become a way to solve this serious problem. Still much more effort is needed to bridge the gap between research and the entrepreneurial world (Allen and O'Shea, 2014; Stagars, 2014) in order to foster massive start-up creation. Since the right identification of market needs is of paramount importance to avoid start-up failure (da Silva et al., 2015), the following section tries to justify why the smart eco-efficient built environment is considered an important area for start-up creation.

\subsection{Smart eco-efficient built environment: an untouched start-up pond?}

Civil engineering is known as an area mainly concerned with directing the great sources of power in nature for the use and convenience of man through the construction of large and public infrastructures (bridges, dams, airports, highways, tunnels, etc.) by large construction companies. Never was this area known to be associated with high-tech start-up creation. This constitutes a sign of low innovation, which is confirmed by its low patenting level. In the United States the patenting level on civil engineering falls behind other areas (Rothe, 2006). According to Keefe (2012) very few civil engineers take their innovations to the US Patent and Trademark Office, in contrast to the considerable number of electrical and mechanical engineers who do so. This author gives data that shows that the patenting in the civil engineering area is 7 times less than in mechanical engineering and 10 times less than in electrical engineering. A worldwide study (Fisch et al., 2015) confirms the prone patenting nature of other more innovative areas than civil engineering. This low innovation level undermines the prestige of civil engineering and helps explain the reduction of 
undergraduate applications to civil engineering (Byfield, 2003; Lawless, 2005; Hubbard and Hubbard, 2009; Quapp and Holschemacher, 2013).

Nedhi (2002) stated that civil engineering is not traditionally viewed as high-tech engineering. Even in India this area is viewed as a low-tech one (Chakraborty et al., 2011). As a consequence low starting salaries are normal in this area (Hamill and Hodgkinson, 2003). The fact that construction enterprises have low productivity (Fulford and Standing, 2014) and have to compete for lower bids having lower and lower profit margins (Morby, 2014) and also have to face increasing and fierce Chinese competition already capable of building a dozen-story structure in just a few weeks (McKinsey, 2014; CWO, 2015) means that construction enterprises in the future will have less and less financial possibilities to offer high and attractive paychecks to civil engineers. Still, civil engineering has an important role to play given the environmental impact of the construction industry that will be exacerbated in the next decades due to the growth in world population. By 2050 urban population will almost double, increasing from approximately 3.4 billion in 2009 to 6.4 billion in 2050 (WHO, 2014). Recent estimates on urban expansion suggests that by 2030 a high probability exists (over 75\%) that urban land cover will increase by 1.2 million $\mathrm{km}^{2}$ (Seto et al., 2012). Since the global construction industry consumes more raw materials (about $3000 \mathrm{Mt} / \mathrm{year}$, almost $50 \%$ by weight) than any other economic activity, the previously mentioned urban expansion will dramatically increase that consumption (Ashby, 2015). This not only will make it more difficult to reduce greenhouse gas emissions for which the built environment is a significant contributor (representing 30\% of related emissions), but will also increase pressure on biodiversity loss, which is crucial for the survival of humanity (Wilson, 2003). It is worth remembering that humanity has already transgressed the planetary boundaries for climate change, rate of biodiversity loss, and changes to the global nitrogen cycle (Rockstrom et al., 2009). As a consequence, the role of civil engineering will be much more relevant if it was able to reinvent itself into an eco-efficient one with high added value.

The concept of eco-efficiency was first coined in the book, Changing Course (Schmidheiny, 1992), in the context of 1992 Earth Summit process. This concept includes "the development of products and services at competitive prices that meet the needs of humankind with quality of life, while progressively reducing their environmental impact and consumption of raw materials throughout their life cycle, to a level compatible with the capacity of the planet." Thus the eco-efficient built environment concerns reducing its environmental impact while enhancing the quality of life of its users. In this context the development of technologies for the smart eco-efficient built environment may provide the body of innovative knowledge that is known to be critical for entrepreneurs to transform innovative ideas into commercial products and services (Agarwal and Shah, 2014).

In the last decades nanotechnology became a hot area, crossing different scientific areas from electronics to life sciences; however, only in the last few years have the nanotech investigations for the construction industry begun to have enough expression justified by the published works on that particular field (Smith and Granqvist, 2011; Pacheco-Torgal et al., 2013a). A Scopus search of journal papers 
containing the terms "nanotechnology" and "eco-efficient construction" shows that a research shift from cement nanotech to nanotech energy-efficient materials has occured.

A high priority nanotech-related field concerns the development and production of cool materials incorporating new advanced nanomaterials (Santamouris et al., 2011). Cool materials have high solar reflectance, allowing for the reduction of energy cooling needs in summer. These materials are especially important for building energy efficiency because as a consequence of climate change, building cooling needs are expected to increase in the coming years. According to the IEA (2013), energy consumption for cooling is expected to increase sharply by 2050 , by almost $150 \%$ globally, and by $300-600 \%$ in developing countries. The Cool-Coverings FP7 project (Escribano and Keraben Grupo, 2013) aimed at the development of a novel and cost-effective range of nanotech-improved coatings to substantially improve near-infrared reflective properties. The author's view is that this area could merit the formation of successful start-ups. Another important nanotech field concerns switchable glazing technology-based materials that make it possible to construct glazings whose throughput of visible light and solar energy can be switched to different levels depending on the application of a low DC voltage (electrochromics) or on the temperature (thermochromics), or even by using hydrogen (gasochromics). This technology has a large potential to minimize the energy use in buildings and allow for the nearly zero-energy building target (Granqvist, 2013; Pacheco-Torgal et al., 2013b; Favoino et al., 2015). Several commercial solutions are already available on the market (SAGE Electrochromics-USA, Econtrol Glas, Saint Gobain Sekurit, and GesimatGermany, among others) with a service life of 30 years and capable of 100,000 switching cycles, but their cost-efficiency is far from an optimum condition. ChromoGenics is a relevant company operating in this field that was established in 2003 as the outcome of over 20 years of research on electrochromic materials by Professor Claes-Göran Granqvist and his team at the Ångström Laboratory at Uppsala University in Sweden. Using a laminated electrochromic plastic foil, ConverLight ${ }^{\mathrm{TM}}$, rather than coating the glass itself, ChromoGenics has contributed to a more scalable and cost-effective smart-glass manufacturing. The most challenging point of smart windows at the moment is their higher cost compared to the other glazing technologies (Cuce and Riffat, 2015). Hee et al. (2015) states that due to the higher costs of dynamic glazing, it is more suitable to be installed in the building that needs high performance in terms of day-lighting and energy savings such as commercial buildings.

Biotechnology is one of the world's fastest growing industries that could constitute a hot area allowing for radical changes in the eco-efficiency of construction materials and technologies. Since this area is one of the six key enabling technologies that will be funded under the EU Framework Programme Horizon 2020 (Pacheco-Torgal, 2014) this can also foster the development of start-ups for the eco-efficient built environment. The use of biotechnology for indoor air purification is also a crucial biotech innovation of major significance for the eco-efficient built environment with high marketable potential. US expenditures for indoor air quality (IAQ) are currently $\$ 23$ billion per year, or, accounting for uncertainty, between $\$ 18$ and $\$ 30$ billion per year (Mudarri, 2014). IAQ is a main issue for researchers motivated by the time 
that humans spend indoors, the wide range of pollutants present in indoor air, their concentration and toxicity, and the higher indoor concentrations with respect to outdoor ones. Building ventilation is a simple and efficient measure to improve IAQ (provided that the building is not located in a polluted city or near polluted areas like high-traffic roads). However, high ventilation rates are associated with high energy costs. Wang and Zhang (2011) developed an active biofiltration system based on carbon as a hydroponic substrate for indoor plants reporting a reduction in ventilation energy costs.

Currently some biofilters are already on the market, like for instance the active modular phytoremediation systems developed by CASE, cohosted by Rensselaer Polytechnic Institute and Skidmore, Owings \& Merrill LLP (Torpy et al., 2014). Still the development of improved biofilters could merit the creation of new start-ups. Another important biotech feature concerns the production of bioenergy through microalgae photobioreactors (PBRs) integrated as facades or roofs. This technique seems to have high potential for start-up creation. Microalgae has a high oil content and most importantly, shows an extremely rapid growth. It doubles its biomass within 24 hours, being the fastest growing organism in the world. This is about 100-200\% higher than any other energy crop (Chisti, 2007). The major constraint to the commercial-scale algae farming for energy production is the cost factor. But since microalgae have the ability to assimilate nutrients like nitrogen and phosphates (which are present in wastewaters) into the cells for its growth, the application of microalgae for wastewater treatment can be an interesting option to enhance its economic value and at the same time to solve environmental problems related to wastewater management. As for the use of architectural PBRs, their synergy generated by summation profits can turn the architecture into something iconic, environmentally didactic, active energetically, surface-saving, and environmentally friendly (Cervera and Pioz, 2014).

Smart-home solutions are another important area (especially for users with special needs) that may unleash a lot of business opportunities for built environment professionals. The investigation on smart homes began in the 1990s with the MIT pioneering work "Smart rooms" (Pentland, 1996). A case study that also took place in the 1990s of an adaptive house that used neural networks to control air heating, lighting, ventilation, and water heating without previous programming by the residents was described by Chan et al. (2008). This system, termed ACHE (adaptive control of home environments), attempted to economize energy resources while respecting the lifestyle and desires of its inhabitants. De Silva et al. (2012) defines it as a "home-like environment that possesses ambient intelligence and automatic control, which allow it to respond to the behavior of residents and provide them with various facilities." They also mention that currently there are three major application categories. The first category aims at providing services to the residents and includes smart homes that provide elder care, smart homes that provide health care, and smart homes that provide child care. The second category aims at storing and retrieving multimedia captured within the smart home, in different levels from photos to experiences. The third area is about surveillance, where the data captured in the environment are processed to obtain information that can help to raise alarms in order to 
protect the home and the residents from burglaries, theft, and natural disasters like flood, and so on.

Other authors (Wong et al., 2005) mentioned that intelligent buildings started three decades ago. Still it was only in 2006 that Derek Clements-Croome (2013) formed the Intelligent Buildings Group of the Chartered Institution Services Engineers. For this author intelligent buildings are not only responsive to the occupants' needs but at the same time are sustainable in terms of energy and water consumption and maintain a minimal impact on the environment in terms of emissions and waste including the use of self-healing and smart-materials technology (Clements-Croome, 2011). Several terms are used in this respect including self-aware and sentient buildings (Mahdavi, 2008); however, this concept has not been widely used. The concept of smart buildings has been associated with a more advanced grouping (Buckman et al., 2014) that integrates and accounts for intelligence, enterprise, control, and materials and construction as an entire building system, with adaptability, not reactivity, at its core, in order to meet the drivers for building progression: energy and efficiency, longevity, and comfort and satisfaction.

Apart from the discussion between the intelligent/smart/sentient concepts the important thing to retain is that the overall objective relies on the development of housing to be healthier, safer, and comfortable (GhaffarianHoseini et al., 2013). In the next few years three major disruptive drivers (big data/Internet of Things (IoT)/cloud computing) will radically change smart homes. The data generated from thousands of home sensors and home appliances that are able to connect to each other, to send data, and to be managed from cloud network services will boost smart home advantages (Kirkham et al., 2014). Thanks to IoT, the largest software companies will make a shift to the physical world as did Google, which acquired a company producing thermostats to enter its trademarks in the smart-home world (Borgia, 2014). This highlights the importance of building energy efficiency. This importance is also shared by some works on the IoT area (Moreno et al., 2014) and is especially needed to address ambitious energy consumption targets for instance like the Zürich 2000 Watt Society (Zurich, 2011). More on the role of the energy-efficient built environment to European smart cities can be found in Kylili and Fokaides (2015). Smart homes will be able to assess an occupant's satisfaction, which is one of the main shortcomings of built environment, even in green buildings that surprisingly are not as occupant-friendly as previously alleged. In a large-scale occupant survey Guo et al. (2013) found that in some green buildings lower satisfaction and comfort were reported. Hirning et al. (2014) reported discomfort glare in five green buildings in Brisbane, Australia. Altomonte and Schiavon (2013) found that LEED-certified buildings show no significant influence on occupant satisfaction. In a postoccupancy study of a LEED Platinum building some occupants mentioned thermal discomfort (Hua et al., 2014).

The assessment of the occupant's feedback in smart homes will trigger interactive actions to adapt homes' performance accordingly. This is a leap from neutral comfort (absence of discomfort) into a new one in which the well-being of occupants is at the heart of the smart-home concept (Clements-Croome, 2014). Older people constitute an important group of users with special needs that could benefit from smart-home features. In the next decades this group will increase dramatically. The global population 
of people over the age of 65 is expected to more than double from 375 million in 1990 to 761 million by 2025 (Dishman, 2004). By 2040 it is expected to reach 1300 million (Kinsella and He, 2009). Between 2100 and 2300 the proportion of the world population in the 65 or over age group (the retirement age in most countries) is estimated to increase by $24-32 \%$, and the 80 or over age group will double from $8.5 \%$ to $17 \%$ (UN, 2004). Elderly people prefer to live in their own house rather than in hospitals, which means that is important that homes can be studied and adapted to enhance elderly users' satisfaction. For instance home sensors can be used to balance daylight exposure and artificial light in order to guarantee enough light to maintain circadian rhythmicity, or else to warn elderly occupants on heat waves and high UV exposure. Sensors can also be used to detect air pollutants like volatile organic compounds and trigger ventilation to reduce its concentration. This means that the design of a built environment to help elderly occupants being independent in their homes is a crucial issue, to be addressed by built environment professionals integrating multidisciplinary teams.

Redirecting the focus of civil engineering from construction and rehabilitation of grand infrastructures to smart eco-efficient built environment-related areas and the needs of individual home users will enlarge the number of future clients. Different user problems will require different tailored solutions and this may represent a wide market of millions of clients that may foster high-tech start-up creation.

Other books have already been written about start-ups. However, as far as the author is concerned, none was published concerning civil engineering-based startups or start-up creation for the built environment. Parts 2 and 3 of this book cover a wide range of innovative technologies (ideas) that could generate start-ups. However, although innovative ideas are crucial they are not enough for start-up creation-the ability to put those ideas to work is. That is why the first part of this book assembles an important group of issues that are crucial for those who need to set their start-up in motion.

\subsection{Outline of the book}

This book provides an updated state-of-the-art review on the start-up creation for the smart eco-efficient built environment.

The first part encompasses an overview on business plans, start-up financing, marketing, creativity, and intellectual property (Chapters $2-8$ ). Chapter 2 concerns business plan basics for engineers. It discusses the unique characteristics and challenges of technology-driven business environments, and describes the two key components of the business planning process: the articulation and the development of a viable business model, and managing the scaling up and the growth of the business.

Chapter 3 addresses the concept of the lean start-up approach as a way of reducing the risk of starting new firms (or launching new products) and enhancing the chances for success by validating the products and services in the market with customers before launching it in full scale. 
Chapter 4 discusses the pro and cons of different start-up financing options. These include debt financing, equity financing, convertible debt financing, and crowdfunding.

Marketing for start-ups is the subject of Chapter 5. It describes how start-ups interact, how their networks are built, and what contributions various actors have in terms of how they coinfluence each other and add to the possibility of the start-up to develop in the long-term.

In Chapter 6, a representative and pertinent survey is presented, covering research literature about measuring and defining entrepreneurship, and more especially, entrepreneurial creativity. It discusses a minimalist model for measuring entrepreneurial creativity based on three criteria: timing, cognitive capacity, and quantifiable changes. An application of the model to information about the career of three well-known entrepreneurs is made.

Chapter 7 reviews intellectual property-related issues. It includes forms of intellectual property rights, trademarks, industrial designs, patents and utility models, copyrights, and trade secrets. A review of the historical development of the intellectual property protection is made and the regulatory aspects of the intellectual property protection are discussed.

Nano- and biotechnologies for eco-efficient buildings are the subject of Part II (Chapters 8-13).

Chapter 8 is concerned with nano-based thermal insulation for energy-efficient buildings. It starts with a review on the advantages and disadvantages of traditional building thermal insulation materials. A special focus is given to nano-based thermal insulation materials. Comments on start-up creation for manufacturing nano-based thermal insulation for energy-efficient buildings are made.

Chapter 9 is related to nano-based thermal storage technologies for building energy efficiency. Synthesis and characterization of the heat transfer and thermal storage properties of nano phase change material (nanoPCM) are included. A review of nanoPCM applications and their potential energy benefits is performed. The chapter also discusses whether the higher conductivity of nanoPCM is desirable in all applications and if the property enhancements are worth the cost and effort needed to create nanoPCMs.

Chapter 10 covers nano-based chromogenic technologies for building energy efficiency, especially thermochromic and electrochromic windows. Application performances were demonstrated through both experiments and simulations. A guidance on the performance improvement was also discussed.

Chapter 11 analyzes façade-integrated PBRs for building energy efficiency. A review on microalgae and the different type of PBRs is included. Design and scale-up parameters are discussed. The role of PBRs in building, particularly as building facades, is also discussed. This chapter is closed with relevant comments on start-up creation to the development of innovative PBRs for the built environment.

Biotechnologies for improving indoor air quality is the subject of Chapter 12. It reviews the different indoor air pollutants and current air cleaning methods. It addresses the theoretical basics on biotechnologies for air cleaning, the types of bioreactors, and the evaluation of bioreactors performance. Also discussed are the opportunities and 
challenges of using bioreactors for indoor air cleaning. The removal of specific indoor air pollutants are also covered as well as future trends in this field.

Chapter 13 addresses the use of biobased plastics for building facades. Comments on feedstocks, resource efficiency, and recycling are included. Requirements for use of biobased plastics as building components are addressed. Performance of some biobased plastics concerning fire resistance, heat stability, and weathering resistance is also addressed. A case study of a biobased plastic façade is included.

Finally Part III (Chapters 14-19) deals with algorithms, big data, and IoT for eco-efficient and smart buildings.

Chapter 14 is concerned with the development of algorithms for building retrofit. It contains an overview of different methodologies to deal with multiobjective projects, and methods to assist and define the retrofit interventions is described.

Chapter 15 looks at the use of control algorithms in lighting systems for high energy savings and for the fulfillment of lighting requirements. This chapter introduces light control algorithms as enabler of differentiation, which is a key requirement for a successful start-up rollout. Moreover, the proposed control lighting systems are customized and implemented in three real operational environments: two hospitals and one office building.

Chapter 16 is concerned with the use of big data and cloud computing for building energy efficiency. This chapter presents the framework of a smart-decision support system (SDSS) that integrates smart-grid big data analytics and cloud computing for building energy efficiency. A real-world smart metering infrastructure was installed in a residential building for the experiment. The SDSS accurately identified the building energy consumption patterns and forecasted future energy usage.

Chapter 17 addresses the case of intelligent-decision support systems and the IoT for the smart built environment. This chapter outlines the general theory of the IoT in the built environment. An analysis of possibilities to integrate intelligent decision support systems with IoT in the built environment is carried out. The main trends and the future of IoT in the built environment are discussed.

Chapter 18 is concerned with app programming and its use for smart-building management systems. An overview of different issues to consider when developing apps is included. A discussion about app types and how they are used is also included.

Chapter 19 deals with the usage of smart-home technologies for home security, the available networking technologies, and their benefits and vulnerabilities. A number of existing products are presented, in terms of the features provided for making a home secure, along with their advantages and potential disadvantages.

\section{References}

Allen, T., O’Shea, R., 2014. Building Technology Transfer within Research Universities: An Entrepreneurial Approach. Cambridge University Press.

Agarwal, R., Shah, S., 2014. Knowledge sources of entrepreneurship: firm formation by academic, user and employee innovators. Research Policy 43, 1109-1133. 
Altomonte, S., Schiavon, S., 2013. Occupant satisfaction in LEED and Non-LEED certified buildings. Building and Environment 68, 66-76.

Ashby, F., 2015. Materials and Sustainable Development, first ed. Butterworth-Heinemann, Elsevier, Oxford, UK.

Astebro, T., Bazzazian, N., Braguinsky, S., 2012. Startups by recent university graduates and their faculty: implications for university entrepreneurship policy. Research Policy 41, 663-677.

Baudeau, N., 1910. In: Dubois, A. (Ed.), Première introduction à la philosophie Économique. P. Geuthner, Paris.

Baumol, W.J., 2008. Small enterprises, large firms, productivity growth and wages. Journal of Policy Modeling 30 (4), 575-589.

Biavaschi, C., Eichhorst, W., Giulietti, C., Kendzia, M., Muravyev, A., Pieters, J., Rodriguez-Planas, N., Schmidl, R., Zimmerman, K., 2015. Youth Unemployment and Vocational Training. IZA Policy Paper No. 6890. Institute for the Study of Labor, Bonn, Germany.

Byfield, M.P., 2003. British civil engineering skills: defusing the time bomb. Proceedings of the Institution of Civil Engineers: Civil Engineering 156 (4), 183-186.

Borgia, E., 1 December 2014. The internet of things vision: key features, applications and open issues. Computer Communications 54, 1-31.

Buckman, A., Mayfield, M., Beck, S., 2014. What is a smart building? Smart and Sustainable Built Environment 3 (2), 92-109.

Cassar, G., 2014. Industry and startup experience on entrepreneur forecast performance in new firms. Journal of Business Venturing 29, 137-151.

Cervera, R., Pioz, J., 2014. Architectural bio-photo reactors: harvesting microalgae on the surface of architecture. In: Pacheco-Torgal, F., Labrincha, J., Diamanti, M., Yu, C.-P., Lee, H.K. (Eds.), Biotechnologies and Biomimetics for Civil Engineering. Springer, London, pp. 163-180.

Chakraborty, S., Iyer, N., Krishna, P., Thakkar, S., 2011. Assessment of Civil Engineering Inputs for Infrastructure Development. Indian National Academy of Engineering.

Chan, M., Esteve, D., Escriba, C., Campo, E., 2008. A review of smart homes - present state and future challenges. Computer Methods and Programs in Biomedecine 91, 55-81.

Chisti, Y., 2007. Biodiesel from microalgae. Biotechnology Advances 25, 294-306.

Clements-Croome, D., 2014. Sustainable Intelligent Buildings for Better Health, Confort and Well-being. Report for Denzero project.

Clements-Croome, D., 2013. Intelligent Buildings: An Introduction. Earthscan, Routledge.

Clements-Croome, D., 2011. Sustainable intelligent buildings for people: a review. Intelligent Buildings International 3, 67-86.

Cohen, S., Hochberg, Y.V., March 30, 2014. Accelerating Startups: The Seed Accelerator Phenomenon. Available at SSRN: http://ssrn.com/abstract=2418000 or http://dx.doi.org/ 10.2139/ssrn.2418000.

Construction Week Online-CWO, 2015. Chinese Firm Builds World's Tallest Prefab Tower. http://www.constructionweekonline.com/article-32916-chinese-firm-builds-worlds-tallestprefab-tower/.

Cuce, E., Riffat, S., 2015. A state-of-the-art review on innovative glazing technologies. Renewable and Sustainable Energy Reviews 41, 695-714.

Dishman, E., 2004. Inventing wellness system for aging in place. IEEE Computer Magazine 37 (5), 34-41.

da Silva, F., Romulo, F., Pinto, R., Galegale, N., Akabane, G., 2015. Why technology-based startups fail? An it management approach. In: Production and Operations Management Society, POMS 26th Annual Conference,Washington. http://www.pomsmeetings.org/ ConfProceedings/060/Full\%20Papers/final_full_paper.htm. 
De Silva, L., Morikawa, C., Petra, I., 2012. State of the art of smart homes. Engineering Applications of Artificial Intelligence 25, 1313-1321.

de Lemos, H., 2014. The failure of early-stage technology startups in Brazil: a study about the contributing factors to the early-death of startups between 2009 and 2014 in Southeastern Brazil. Master Dissertation. Fundação Getulio Vargas. http://bibliotecadigital.fgv.br/ dspace/handle/10438/13098 (accessed on 3 of September of 2015).

Di Gregorio, D., Shane, S., 2003. Why some universities generate more start-ups than others. Research Policy 32, 209-227.

Escribano, M.A.B., Keraben Grupo, S.A., 2013. Development of a Novel and Cost-effective Range of Nanotech Improved Coatings to Substantially Improve NIR (Near Infrared Reflective) Properties of the Building Envelope. FP7 Project. http://cordis.europa.eu/ project/rcn/94644_en.html.

Etzkowitz, H., 2003. Research groups as 'quasi-firms': the invention of the entrepreneurial university. Research Policy 32, 109-121.

Favoino, F., Overend, M., Jin, Q., 2015. The optimal thermo-optical properties and energy saving potential of adaptive glazing technologies. Applied Energy 156, 1-15.

Fisch, C., Hassel, T., Sandner, P., Block, J., 2015. University patenting: a comparison of 300 leading universities worldwide. Journal of Technology Transfer 40, 318-345.

Fulford, R., Standing, C., 2014. Construction industry productivity and the potential for colaborative practice. International Journal of Project Management 32 (2), 315-326.

GhaffarianHoseini, A., Dahlan, N., Berardi, U., GhaffarianHoseini, A., Makaremi, N., 2013. The essence of future smart houses: from embedding ict to adapting to sustainability principles. Renewable and Sustainable Energy Reviews 24, 593-607.

Guerrero, M., Cunningham, J., Urbano, D., 2015. Economic impact of entrepreneurial universities' activities: an exploratory study of the United Kingdom. Research Policy 44, 748-764.

Godin, B., Gingras, Y., 2000. The place of universities in the system of knowledge production. Research Policy 29, 273-278.

Guo, Z., Prasad, D., Lau, S., 2013. Are green buildings more satisfactory and comfortable? Habitat International 39, 156-161.

Granqvist, C.-G., 2013. Switchable glazing technology for eco-efficient construction. In: Pacheco-Torgal, F., Diamanti, V., Nazari, A., Granqvist, C.G. (Eds.), Nanotechnology in Eco-efficient Construction. Materials, Processes and Applications. Woodhead Publishing Limited Abington Hall, Cambridge, UK, pp. 236-269.

Hamill, L., Hodgkinson, L., 2003. Civil engineering's image in schools - and how to change it. Proceedings of the ICE - Civil Engineering 156 (2), 78-85.

Hee, W., Alghoul, M., Bakhtyar, B., Elayeb, O., Shameri, M., Alrubaih, M., Sopian, K., 2015. The Role of window glazing on daylighting and energy saving in buildings. Renewable and Sustainable Energy Reviews 42, 323-343.

Hirning, M.B., Isoardi, G.L., Cowling, I., 2014. Discomfort glare in open plan green buildings. Energy and Buildings 70, 427-440.

Hsu, A., Shen, Y.-C., Yuan, B., Chou, C., 2014. Toward successful commercialization of university technology: performance drivers of university technology transfer in Taiwan. Technological Forecasting \& Social Change 92, 25-39.

Hua, Y., Goçer, O., Gocer, K., 2014. Spatial mapping of occupant satisfaction and indoor environment quality in a LEED platinum campus building. Building and Environment 79, 124-137.

Hubbard, B.J., Hubbard, S.M., 2009. Activities to enhance civil engineering recruitment and coordination with industry. Transportation Research Record 22-30. 
IEA, 2013. Technology Roadmap: Energy Efficient Building Envelopes. International Energy Agency, Paris.

Kalar, B., Antoncic, B., 2015. The entrepreneurial university, academic activities and technology and knowledge transfer in four european countries. Technovation 36-37, 1-11.

Keefe, S., 2012. Patent eligibility: an open fieled for civil engineering. Civil Engineering 70-73.

Kinsella, K., He, W., 2009. An Aging World: 2008. US Census Bureau, Washington DC.

Kirchhoff, B.A., 1989. Creative destruction among industrial firms in the United States. Small Business Economics 1 (3), 161-173.

Kirkham, T., Armstrong, D., Djemame, K., Jiang, M., 2014. Risk driven smart home resource management using cloud services. Future Generation Computer Systems 38, 13-22.

Kylili, A., Fokaides, P., 2015. European smart citties: the role of zero energy buildings. Sustainable Citties and Society 15, 86-95.

Krabel, S., Mueller, P., 2009. What drives scientists to start their own company? An empirical investigation of Max Planck Society Scientists. Research Policy 38, 947-956.

Kshetri, N., 2015. Success of crowd-based online technology in fundraising: an institutional perspective. Journal of International Management 21, 100-116.

Lacy, S., 2011. Peter Thiel: We're in a Bubble and It's Not the Internet. It's Higher Education. Techcrunch.

Landry, R., Amara, N., Rherrad, I., 2006. Why are some university researchers more likely to create spin-offs than others? Evidence from Canadian universities. Research Policy 35, 1599-1615.

Lawless, A., 2005. A wake up call to address the capacity crisis in SA civil engineering. Civil Engineering/Siviele Ingenieurswese 13 (10), 40-43.

Leyden, D., Link, A., Siegel, D., 2014. A Theoretical analysis of the role of social networks in entrepreneurship. Research Policy 43, 1157-1163.

Leydesdorff, L., Etzkowitz, H., 2001. The transformation of university-industry-government relations. Electronic Journal of Sociology 5 (4).

Li, S., Whalley, J., Xing, C., 2014. China's higher education expansion and unemployment of college graduates. China Economic Review 30, 567-582.

Louçã, F., 2014. The elusive concept of innovation for Schumpeter, Marschak and the early econometricians. Research Policy 43, 1442-1449.

Lundqvist, M., 2014. The importance of surrogate entrepreneurship for incubated Swedish technology ventures. Technovation 34, 93-100.

Macauley, C., 2015. Capitalism's renaissance? The potential of repositioning the financial 'meta-economy'. Futures 68, 5-18.

Mahdavi, A., 2008. Anatomy of a cogitative building. In: EWork and EBusiness in Architecture, Engineering and Construction - Zarl \& Scherer. Taylor and Francis.

Maidique, M.A., Zirger, B.J., 1984. A study of success and failure in product innovation: the case of the US electronics industry. IEEE Transactions on Engineering Management 4, 192-203.

McKinsey, 2014. How to Build a Skyscraper in Two Weeks. Insigths \& Publications. http:// www.mckinsey.com/insights/engineering_construction/how_to_build_a_skyscraper_in_ two_weeks.

Miller, P., Bound, K., 2011. The Startup Factories: The Rise of Accelerator Programmes to Support New Technology Ventures. NESTA, London.

Min, W., 2015. The challenge facing Chinese higher education in the next two decades. International Higher Education 80, 11-12.

Mollick, E., 2014. The dynamics of crowdfunding: an exploratory study. Journal of Business Venturing 29, 1-16. 
Mowery, D., Ziedonis, A., 2002. Academic patent quality and quantity before and after the Bayh-Dole act in the United States. Research Policy 31, 399-418.

Mowery, D., Nelson, R., Sampat, B., Ziedonis, A., 2001. The growth of patenting and licensing by U.S. universities: an assessment of the effects of the Bayh-Dole Act of 1980. Research Policy 30, 99-119.

Mowery, D.C., Nelson, R.R., Sampat, B.N., Zeidonis, A.A., 2004. Ivory Tower and Industrial Innovation. Stanford University Press, Stanford.

Morby, A., February 10, 2014. Cost Rises Squeeze Builders Profit Margins. Construction Enquirer.

Moreno, M.V., Úbeda, B., Skarmeta, A., Zamora, M., 2014. How can we tackle energy efficiency in IoT based smart buildings? Sensors 14, 9582-9614.

Mudarri, D., 2014. National expenditures, jobs, and economic growth associated with indoor air quality in the United States. Journal of Environmental Health 26-31.

Nehdi, M., 2002. Crisis of civil engineering education in information technology age: analysis and prospects. Journal of Professional Issues Engineering Education and Practice 128 (3), $131-137$

O'Shea, R.P., Allen, T.J., Chevalier, A., Roche, F., 2005. Entrepreneurial orientation, technology transfer and spinoff performance of U.S. universities. Research Policy 34 (7), 994-1009.

Ouimet, P., Zarutskie, R., 2014. Who works for startups? The relation between firm age, employee age, and growth. Journal of Financial Economics 112, 386-407.

Pacheco-Torgal, F., 2014. Eco-efficient construction and building materials research under the EU Framework Programme Horizon 2020. Construction and Building Materials 51, $151-162$.

Pacheco-Torgal, F., Mistretta, M., Kaklauskas, A., Granqvist, C.G., Cabeza, L.F., 2013b. Nearly Zero Energy Building Refurbishment: A Multidisciplinary Approach. Springer-Verlag London Ltd.

Pacheco-Torgal, F., Diamanti, M.V., Nazari, A., Granqvist, C.G., 2013a. Nanotechnology in Eco-efficient Construction. Woodhead, Cambridge, UK.

Pentland, A., 1996. Smart Rooms. Scientific American, pp. 54-62.

Quapp, U., Holschemacher, K., 2013. Efforts to reduce the drop-out rate in civil and structural engineering programs. In: Research and Applications in Structural Engineering, Mechanics and Computation. Proceedings of the 5th International Conference on Structural Engineering, Mechanics and Computation, SEMC 2013, pp. 2545-2548.

Roberts, E., 2014. In foreword. Allen, T. and ÓShea, R. (2014) Building Technology Transfer within Research Universities: An Entrepreneurial Approach. Cambridge University Press.

Rockström, J., Steffen, W., Noone, K., Persson, Å., Chapin III, F.S., Lambin, E., Lenton, T.M., Scheffer, M., Folke, C., Schellnhuber, H., Nykvist, B., De Wit, C.A., Hughes, T., van der Leeuw, S., Rodhe, H., Sörlin, S., Snyder, P.K., Costanza, R., Svedin, U., Falkenmark, M., Karlberg, L., Corell, R.W., Fabry, V.J., Hansen, J., Walker, B., Liverman, D., Richardson, K., Crutzen, P., Foley, J., 2009. Planetary boundaries: exploring the safe operating space for humanity. Ecology and Society 14 (2), 32.

Roy, S., 2014. Reengineering our vision: breaking through the paradoxical crisis of unemployment. International Journal of Human Resource Management 1, 11-17.

Rothe, C., 2006. Using patents to advance the civil engineering profession. Civil Engineering $67-73$.

Roure, J.B., Keeley, R.H., 1990. Predictors of success in new technology based ventures. Journal of Business Venturing 5 (4), 201-220. 
Sadler, D., 2015. The Challenges Facing Chinese Higher Education. And Why They Matter. The Observatory of Borderless Higher Education.

Santamouris, M., Synnefa, A., Karlessi, T., 2011. Using advanced cool materials in the urban built environment to mitigate heat islands and improve thermal comfort conditions. Solar Energy 85, 3085-3102.

Schmid, G., 2015. Youth Unemployment in India: From a European and Transitional Labour Market Point of View. IZA Policy Paper No. 95. Institute for the Study of Labor, Bonn, Germany.

Schumpeter, J., 1934. The Theory of Economic Development (R. Opie, Trans.). Harvard University Press, Cambridge.

Schwienbacher, A., Larralde, B., 2012. Crowdfunding of small entrepreneurial ventures. In: Cumming, D. (Ed.), The Oxford Handbook of Entrepreneurial Finance. Oxford University Press, New York.

Seto, K.C., Buneralp, B., Hutyra, L.R., 2012. Global forecasts of urban expansion to 2030 and impacts on biodiversity and carbon pools. PNAS 17-21.

Siegel, D.S., Veugelers, R., Wright, M., 2007. Technology transfer offices and commercialization of university intellectual property: performance and policyimplications. Oxford Review of Economic Policy 23, 640-660.

Smith, G., Granqvist, C., 2011. Green Nanotechnology: Solutions for Sustainability and Energy in the Built Environment. Taylor \& Francis Group.

Stagars, M., 2014. University Startups and Spinoffs. Guide for Entrepreneurs in Academia. Springer.

STAC, 2014. The Future of Europe Is Science. A report of the President's Science and Technology Advisory Council (STAC). https://ec.europa.eu/programmes/horizon2020/en/ news/report-pres-barrosos-science-and-technology-advisory-council-stac-future-europescience-oct2014.

Stephan Schmidheiny with BCSD, 1992. Changing Course: A Global Perspective on Development and the Environment. MIT Press, Cambridge, MA.

Stemler, A., 2013. The JOBS Act and crowdfunding: harnessing the power-and money-of the masses. Business Horizons 56, 271-275.

Swart, R., December 10, 2013. World Bank: Crowdfunding Investment Market to Hit $\$ 93$ Billion by 2025. http://www.pbs.org/mediashift/2013/12/worldbankcrowdfunding investmentmarkettohit93billionby2025/.

Teixeira, A., Coimbra, C., 2014. The determinants of the internationalization of Portuguese university spin-offs: an empirical investigation. Journal of International Entrepreneurship $12,270-308$.

Thiel, P., Masters, B., 2014. Zero to One: Notes on Startups or How to Build the Future. Crown Business, New York.

Thurik, A., Stam, E., Audretsch, D., 2013. The rise of the entrepreneurial economy and the future of dynamic capitalism. Technovation 33, 302-310.

Torpy, F., Irga, P., Burchett, M., 2014. Reducing indoor air pollutants through biotechnology. In: Pacheco-Torgal, F., Labrincha, J., Diamanti, M., Yu, C.-P., Lee, H.K. (Eds.), Biotechnologies and Biomimetics for Civil Engineering. Springer, London, pp. 181-210.

UN Department of Economic and Social Affairs, 2004. Population Division. World Population in 2300. United Nations, New York.

Visintin, F., Pittino, D., 2014. Founding team composition and early performance of university - based spin-off companies. Technovation 34, 31-43.

Wagner, T., 2012. Creating Innovators: The Making of Young People Who Will Change the World. Scribner/Simon \& Schuster. 
Wang, Z., Zhang, J.S., 2011. Characterization and performance evaluation of a full-scale activated carbon-based dynamic botanical air filtration system for improving indoor air quality. Build Environ 46, 758-768.

Winograd, M., Hais, M., 2014. How Millenials Could Upend Wall Street and Corporate America. Governance Studies and Brooking, pp. 1-19.

Wilson, E.O., 2003. The Future of Life. Vintage, New York, US.

WHO, 2014. Urban Population Growth. Global health observatory. http://www.who.int/gho/ urban_health/situation_trends/urban_population_growth_text/en/.

Wong, J.K.W., Li, H., Wang, S.W., 2005. Intelligent building research: a review. Automation in Construction 14 (1), 143-159.

YC, 2015. Y Combinator. https://www.ycombinator.com/atyc/.

Zurich, 2011. On the Way to the 2000-watt Society. www.stadt-zuerich.ch/2000watt. 